\title{
The Urgency of Legal Politics in the Draft Law on Religious Harmony
}

\section{Indah Setiyowati*) and Siti Rodhiyah Dwi Istinah**)}

$\left.{ }^{*}\right)$ Faculty of Law, Universitas Islam Sultan Agung (UNISSULA) Semarang, E-mail: stwindah07@gmail.com

$\left.{ }^{* *}\right)$ Faculty of Law, Universitas Islam Sultan Agung (UNISSULA) Semarang

\begin{abstract}
.
The constitution guarantees the rights and obligations of the Indonesian people, one of which is religious harmony, the conflicts that have occurred to the present day encourage the Government to create higher and binding regulations and have permanent legal force. The purpose of this paper is to find out about legal politics, efforts to create an orderly and harmonious relationship between religious communities and legal politics contained in the Draft Law on Religious Harmony. In this study the researcher used a normative juridical research method, which in this study the researcher took a literature study. Legal politics is a state policy (policy) through state agencies authorized to set the desired regulations. Efforts to create orderly and harmonious relations between religious communities need to pay attention to socio-cultural factors and legal factors. Then, politics in the draft Law on Religious Harmony, namely the purpose of organizing in Religious Harmony, it is necessary to have the rights and obligations of each individual in religion, then to maintain the harmony of religious life it is necessary to have rules that regulate activities that support religious harmony. The activities in question are; Commemoration of holidays, Spreading religion, Funeral of corpses, and Establishment of synagogues.
\end{abstract}

Keywords: Harmony; Law; Politics; Religion; Tolerance.

\section{Introduction}

Indonesia is a pluralistic country, consisting of various ethnic groups, races, religions and groups. But other than that, Indonesia is very famous for its social life and tolerance between individuals. In the composition of the state, there is one human who occupies an area called the state, namely social beings who are gathered in groups and depend on one another. This relationship occurs when humans are born until humans die. Humans are born with a nature to live together, so from that nature emerges a type of law which in its provisions regulates life, namely law.

In the Presidential Decree No. PNPS. 1 of 1965 in conjunction with Act No. 5 of 1969 it is explained that the State guarantees a person to be free to choose the official religion that has been determined by the state, namely Hinduism, Islam, Protestant Christianity, Catholicism, Buddhism and Confucianism. So the Government or in this case is the policy of the Ministry of Religion to be more alert to problems related to the implementation and maintenance of religious harmony because this has been stated in the laws and regulations with the minister of religion and the minister of home affairs.

For example, in the Ambon riots, the conflict between Muslims and Christians in Ambon was motivated by the large number of Muslim immigrants in 1992. 
Certain interests made relations between Muslims and Christians in Ambon heated. These interests make provocateurs play scenarios in the name of SARA. ${ }^{1}$

In relation to the existence of the rule of law and a pluralistic life, it is necessary to have positive rules that regulate the order of Indonesian society. These rules are in the form of rules that are binding and obeyed by all levels of society and are in the form of written rules as the legal basis and basis for coexistence and mutual tolerance without friction ${ }^{2}$.

Inter-religious harmony is a condition in which inter-religious relations are based on tolerance, mutual respect, mutual understanding, respect for equality in the practice of their respective religious teachings and cooperation in the life of society, nation and state. The maintenance of inter-religious harmony is a shared responsibility, both from religious adherents, local government and central government. ${ }^{3}$

The need for a legal product that has permanent legal force as the basis and legal certainty in religious life in Indonesia. These legal products can bind all levels of society in order to create a harmonious and tolerant life as well as order. Based on the brief description above, the author will examine the Urgency of Legal Politics in the Draft Law on Religious Harmony.

\section{Research Methods}

The method used by the author in preparing the journal uses the normative juridical method. The research specification used in this research is descriptive type of analysis. In this study, the author focuses on library research and other materials that can support the discussion of problems. The sources of law used in this research are: Primary Materials are legal materials, Secondary Legal Materials and Tertiary legal materials. The data collection technique carried out in this study used a literature study, collecting data from the results of a review of library materials and secondary data which included primary legal materials, secondary legal materials and tertiary legal materials. The data analysis technique in this study was carried out by qualitative data analysis, namely data collection using laws, theories and legal principles.

\section{Result and Discussion}

\subsection{Efforts to Realize Orderly and Harmonious Relationships Between Religious People}

Religious diversity or religious pluralism is an understanding or a view of religious pluralism. The fact is that there are other religions outside of Islam. Indonesia also has religious pluralism, even in the world. Pluralism is also found in

\footnotetext{
1 Sudjangi, (2003), Konflik Sosial Bernuansa Agama Studi Kasus Kerusuhan Ambon, Jakarta: Kementerian Agama RI Badan Litbang dan Diklat Puslitbang Kehidupan Keagamaan, p.170

2 Chuasanga A., Ong Argo Victoria, "Legal Principles Under Criminal Law in Indonesia and Thailand", Jurnal Daulat Hukum, Vol 2, No 1 (2019) http://jurnal.unissula.ac.id/index.php/RH/article/view/4218

${ }^{3}$ Ministry of Religion RI Research and Development Agency and Training Center for Religious Life, est. Haidlor Ali Ahmad, 2014, Resolusi Konflik Keagamaan di Berbagai Daerah, Jakarta: Kementerian Agama RI Badan Litbang dan Diklat Puslitbang Kehidupan Keagamaan, p. 1
} 
Islam. Islam is divided into several groups. Indonesia has cultural pluralism among Indonesian Muslims, all of these Islamic cultures have different characteristics. ${ }^{4}$

Tolerance is needs that cannot be postponed any longer while providing explanations about religious teachings that emphasize religious tolerance, so that the spirit of religious tolerance can be fostered among adherents of each religion. ${ }^{5}$

Legal politics as a tool or means of steps that can be used by the government to create the desired national legal system and with the national legal system will realize the ideals of the Indonesian nation.

Legal politics includes activities in choosing ideal or universally applicable values and applying these values as role models. Legal politics according to Mahfud MD is "legal policy".(policy line) official law that will be enforced either by making new laws or by replacing old laws in order to achieve the goals of the State. ${ }^{6}$ The factors that influence the harmonious life of religious people are:

\subsubsection{Socio-Cultural Factors}

The diversity of cultural forms between communities and coexistence of life and human nature as social beings need each other and interdependence between other humans, so a form of tolerance is needed that lives in society and is in harmony with one another. Tolerance is acceptance, respect and appreciation for cultural diversity and different expressions. Tolerance becomes harmony in differences that make peace in any name. ${ }^{7}$

Efforts in realizing orderly and harmonious relations between religious communities are:

- Have an attitude of mutual respect for one another and provide freedom between groups in carrying out worship in accordance with their respective beliefs.

- Have an attitude of mutual respect in embracing religion and the role of the government to be responsible for a harmonious and balanced social order.

- Have tolerance and are not allowed to impose people's will.

- Have a high social nature and work together for a common goal.

\subsubsection{Legal Factor}

Article 29 of the 1945 Constitution states that the state guarantees the independence of each resident to embrace their respective religions and to worship according to their respective religions. The guarantee for freedom to embrace religion is absolute and cannot be changed, added or subtracted. Then it is stated in Article 73 of Act No. 39 of 1999 concerning Human Rights which states that human rights can only be limited by and based on law. Restrictions by law can be made to ensure the recognition and respect for human rights.

Social, cultural and political development, if human rights and fundamental freedoms can be fully realized. All human beings have a responsibility in the development and preservation of the environment, both individually and

\footnotetext{
${ }^{4}$ Moh. Mahfud MD, 2014, Politik Hukum di Indonesia, Jakarta: PT Raja Grafindo Persada, p. 1. ${ }^{5}$ Ma'ruf Amin, 2017, Melawan Terorisme dengan Islam, Jakarta: Tim Penanggulangan Terorisme, p. 148. ${ }^{6}$ Moh. Mahfud MD, Op.cit, 2014, p. 1.

${ }^{7}$ Irwan Masduki, 2011, Berislam Secara Toleransi, Bandung: Mizan, p. 4
} 
collectively, taking into account the need for full respect for human rights and fundamental freedoms such as their obligations to society, which can guarantee freedom and full fulfillment as human beings. . ${ }^{8}$

In the Joint Regulation of the Minister of Religion and the Minister of Home Affairs No: 9/8 of 2006 concerning Guidelines for the Implementation of the Duties of Regional Heads/Deputy Regional Heads of Maintenance of Religious Harmony, Empowerment of Religious Harmony Forums and Establishment of Houses of Worship, Article 3 states that the obligation to maintain harmony Religious people in the province are in the hands of the governor. The Minister of Religion of the Republic of Indonesia in 1978-1984 established three basic principles of religious rules or commonly referred to as Tri Religious Harmony, which are the basic rules that are used as guidelines for tolerance between religious communities in Indonesia. The three basic principles are: a. Internal harmony of religious communities, b. Harmony between religious communities, c. Harmony between religious communities and the government.

According to the perspective of the Medina Charter, tolerance between religious communities aims to achieve harmony between religious communities within the country, namely:

- All Muslims, create tolerance for religious harmony between Muslims in a country that is formed in a community and consists of various ethnic and cultural backgrounds.

- Relations between fellow members of the Islamic community and between the Islamic community and other communities are based on the following principles: a). good neighbors, b). help each other and work hand in hand, c). defend those who are being persecuted/troubled d). advise each other e). respect for religious freedom.

\subsection{Legal Politics in the Draft Law on Religious Harmony}

Tolerance is a need that cannot be postponed any longer while providing an explanation of religious teachings that emphasize religious tolerance, so that the spirit of religious tolerance can be fostered among adherents of each religion. ${ }^{9}$

Efforts to enforce inter-religious harmony in Indonesia have been carried out since the founding of the Indonesian nation. These efforts are described in the basis of the State of the Republic of Indonesia, namely Pancasila and the 1945 Constitution of the Republic of Indonesia. Part of the substance of its contents is that the state provides guarantees to protect the existence of religion, the diversity of religious adherents and the beliefs of religious people in Indonesia. These principles indirectly encourage all people of different religions to live in harmony, peace and mutual respect with the motto Bhineka Tunggal Ika. The tradition of

\footnotetext{
${ }^{8}$ Febriansyah Ramadhan and Ilham Dwi Rafiqi. "Antinomy of community participation rights in the law on the environmental sector", Jurnal Daulat Hukum vol. 4 Issue 3 (2021), p. 172 url: Antinomy of Community Participation Rights in the Law on the Environmental Sector | Ramadhan | Iurnal Daulat Hukum (unissula.ac.id), p. 172

${ }^{9}$ Ma'ruf Amin, Op.cit, p. 148
} 
harmony in Indonesia has been entrenched for a long time with these efforts. On the other hand, outbreaks of religious conflict are also difficult to avoid. ${ }^{10}$

An ideology is needed by a nation to bind its people to live together under the auspices of an ideology. Likewise with Indonesia, which has been determined by the founding fathers of Pancasila as the ideology of the Indonesian nation, then automatically Pancasila as an ideology must be obeyed and followed by the whole nation. Pancasila ideology with the principle of Bhineka Tunggal Ika teaches us to always live with a sense of tolerance because of the many different religions, races and sects, but the essence is one too, which is one nation, the Indonesian nation. ${ }^{11}$

Harmony is also interpreted as living together which is colored by a harmonious and peaceful atmosphere, living in harmony means not having conflict, but being united and agreeing in thinking and acting for the sake of realizing mutual prosperity. In harmony everyone can live together without any suspicion, which grows mutual respect and willingness to work together for the common good. Harmony or living in harmony is an attitude that comes from the bottom of the heart that radiates from the willingness to interact with each other as human beings without pressure from any party. ${ }^{12}$

Tolerance and harmony between religious communities are interrelated with one another. Harmony produces tolerance and vice versa, both are related to religious harmony.In the study of Sociology, E. Durheim in his book "The Elementary Forms of the Religious Life" says that attitudes in religion are symbolic manifestations of society and truly one of the characteristics of social phenomena. ${ }^{13}$

The causes of intolerance are due to the lack of active local government, the lack of mutual awareness between religious leaders and community leaders to form interfaith organizations, and the lack of openness of religious minorities. ${ }^{14}$ This attitude occurs because in the group there is privacy of each which is not allowed to be known by the general public.

Religious diversity or religious pluralism is an understanding or view of religious pluralism. The fact is that there are other religions outside of Islam. Indonesia also has religious pluralism, even in the world. Pluralism is also found in Islam. Islam is divided into several groups, Indonesia has cultural pluralism among Indonesian Muslims, all Islamic cultures have different characteristics. ${ }^{15}$

\footnotetext{
${ }^{10}$ Imam Tholkhah, Prolog Survei Nasional Kerukunan Umat Beragama di Indonesia, Haidlor Ali Ahmad, Imam Tholkhah (ed), Jakarta: Badan Litbang dan Diklat Puslitbang Kehidupan Keagamaan, 2013, p. xiv.

${ }^{11}$ Eko Rubiyanto and Munsharif Abdul Chalim, "Counter Terrorism: Case Study On The Radicals Religious Group", Jurnal Daulat Hukum, Vol. 1 Issue 4 (2018), p. 872, url: Counter Terrorism : Case Study On The Radicals Religious Group | Rubiyanto | Jurnal Daulat Hukum (unissula.ac.id).

12 Adhe Ismail Ananda, "Constitution Concept in Implementation of Indonesia State Administration", Jurnal Daulat Hukum, Vo. 4 Issue 2, (2021), p. 123, url: Constitutionalism Concept in Implementation of Indonesian State Administration | Ananda | Jurnal Daulat Hukum (unissula.ac.id), p.1

${ }^{13}$ Durkheim, E., 2014, The Elementary Form of the Religion, Terjemah. Yogyakarta: Diva Press, p. 35.

${ }^{14}$ Tim Peneliti Keagamaan, 2014, Menggali Kearifan Memupuk Kerukunan, Jakarta: Puslitbang Kehidupan Keagamaan, p. 31-302.

${ }^{15}$ Faisal Ismail, Op.cit, p. 19
} 
Society is the foundation of all government affairs that are above it ${ }^{16}$ so that the government must provide welfare, safety and protection to the community so that the community feels safe and the rules are applied to regulate the community to live a better nation and state.

The role of local governments, especially in highlighting religious and social problems in urban communities, is certainly not easy to solve. This is because urban society is socially heterogeneous, individual, highly competitive and is the center of change and urban society is also a shelter for population movement from various places. ${ }^{17}$

The government itself has realized the resistance of inter-religious conflicts. Various government policies have been issued to improve the situation. Various regulatory signs have been passed to minimize conflicts of interest between religious communities. All government regulations that discuss inter-religious harmony in Indonesia. Includes four main problems, namely as follows: ${ }^{18}$

- Establishment of Houses of Worship.

- Religious Broadcasting.

- Religious Aid from Abroad.

- Foreign Workers in the Religious Sector.

The politics of human rights law on religious freedom in Indonesia presents a paradoxical face. On the one hand, the legal guarantee of religious freedom is strengthened, but on the other hand, religious intolerance is also increasing and the state is weak in providing protection for religious freedom. In the Hasyim Asy'ari terminology, the political development of the law of religious freedom in Indonesia is not linear, but full of dynamics as the historical experience of the relationship between the state and religion that has occurred so far because it is influenced by views (perceptions/understandings) between the state and society and between citizens. ${ }^{19}$

In the constitution Article 28E paragraph (1) and paragraph (2) of the 1945 Constitution of the Republic of Indonesia, the two paragraphs read, "Everyone is free to embrace religion and worship according to his religion." That, "Everyone has the right to freedom to believe in beliefs, to express thoughts and attitudes according to his conscience." This guarantee is further strengthened in Article 29 paragraph (2) of the 1945 Constitution of the Republic of Indonesia that, "The State guarantees the independence of each resident to embrace their own religion and to worship according to their religion and beliefs." 20

Therefore, in essence, modern constitutionalism actually concerns the principle of limiting power or what is commonly referred to as the principle of

\footnotetext{
${ }^{16}$ Siti Zuliyah, Triwahyuningsih, "The Implementation of Regional Regulations in the procces of filling in the village civil service", Jurnal Daulat Hukum Vol. 4 Issue 4, (2021) p. 278, url: The Implementation of Regional Regulations in the Process of Filling in the Village Civil Service | Zuliyah Lurnal Daulat Hukum (unissula.ac.id)

${ }^{17}$ Hartono \& Arnicun Aziz, (2011), Ilmu Sosial Dasar, Jakarta: Bumi Aksara, p. 229-230.

18 Jaja Sudarno, 21 June 2017, "Tri Kerukunan Umat Beragama”, Tri Kerukunan Umat Beragama (kemenag.go.id), accessed on 15 September 2021

${ }^{19}$ Hasyim Asy'ari, "Politik Hukum Kebebasan Beragama di Indonesia", in Jurnal Hukum Pandecta, Vol. 6, No.1, January 2011, Fakultas Hukum Universitas Diponegoro, Semarang, 2011, p. 1-14 ${ }^{20}$ Explanation of the Draft Law on Religious Harmony
} 
limited government. That is, in the sense of constitutionalism, the power to prohibit and determine the procedure, so that the government's power guarantees a government that is not arbitrary and a government that is responsible. The idea of regulating and limiting this power naturally arises because of the need to respond to the development of the relative role of general power in the life of the state and society. ${ }^{21}$

However, the restriction on religious freedom cannot be carried out against the law. Article 28J (2) states that "the limitation can only be carried out with the restrictions stipulated in the law". That is, the constitution determines that restrictions on religious freedom can only be carried out with legal instruments in the form of laws in achieving a goal of organizing in Religious Harmony it is necessary to have the rights and obligations of each individual in religion, then to maintain the harmony of religious life it is necessary to have rules that regulate activities. - Activities that support religious harmony. The activities in question are;

- Celebration of holidays;

- The spread of religion;

- Funeral of corpses; and

- The establishment of a house of worship.

The purpose of the implementation of religious harmony is to ensure the fulfillment of the rights of religious communities so that they can develop, interact, and participate optimally in accordance with human dignity and protection from violence and discrimination for the sake of realizing religious harmony of quality and noble character. ${ }^{22}$ The material content contained in the Draft Law on Religious Harmony must contain several principles, namely:

- The principle of tolerance;

- The Principle of Togetherness;

- The principle of non-discrimination; and

- The principle of order.

Religious harmony is a state of inter-religious relations based on tolerance, mutual understanding and mutual respect in the practice of religious teachings and cooperation in social life. The existence of this harmony is very important, besides being a necessity in the context of the protection of human rights, this harmony is also a prerequisite for the realization of national integration, and this integration is a prerequisite for the success of national development. ${ }^{23}$

The rule of law in Indonesia has its own characteristics that may differ from the rule of law applied in various countries. However, for general principles, such as the existence of efforts to protect human rights, the existence of separation or division of power, the implementation of popular sovereignty, the existence of governance based on the prevailing laws and regulations and the existence of a

\footnotetext{
${ }^{21}$ Adhe Ismail Ananda, Loc.cit

${ }^{22}$ Ibnu Rusydi, Siti Zolehah, "Makna Kerukunan Antar Umat Beragama Dalam Konteks Keislaman dan Keindonesiaan”, Journal for Islamis Studies Vol. 1 No. 1 (2018), url: 339662-makna-kerukunanantar-umat-beragama-dala-bd8bd3a9.pdf (neliti.com).

23Masykuri Abdillah, 12 January 2015, Merawat Kerukunan Umat Beragama, Sekolah Pascasarjana MERAWAT KERUKUNAN UMAT BERAGAMA (uinjkt.ac.id), accessed on 14 September 2021
} 
state administrative court are still used as a basis in realize the rule of law in Indonesia. ${ }^{24}$

Philosophically, religious life in Indonesia has not been regulated and has not been listed in written regulations. It is evident that there are many internal problems in the country where this diversity produces different points of view between groups.

Juridically, the Joint Regulation of the Minister of Religion and the Minister of Home Affairs Number 9 of 2006 / Number 8 of 2006 concerning the Duties of Regional Heads / Deputy Regional Heads in Maintaining Religious Harmony, Empowering Religious Harmony Forums and Establishing Houses of Worship is a regulation made to perfecting the Joint Decree of the Minister of Religion and the Minister of Home Affairs No. 1/BER/MDNMAG/1969 concerning the Implementation of the Duties of Government Apparatuses in Ensuring Order and Smooth Implementation of Development and Religious Worship by their adherents which regulates the tasks of the government at the regional level in fostering interreligious harmony by the establishment of a Religious Harmony Forum (FKUB) as an intermediary between religious communities and local governments. The forum is a forum that plays an important role in creating harmony between religious communities.

Sociologically, the need for the formation of legislation to ensure order and harmony of life in the inter-religious community, which is the formation of laws that have high legal force.

Based on the above considerations, it is necessary to establish a Law on Religious Harmony as a follow-up to the implementation of the Joint Regulation of the Minister of Religion and the Minister of Home Affairs Number 9 of 2006 / Number 8 of 2006 concerning the Duties of Regional Heads / Deputy Regional Heads in Maintaining Religious Harmony, Empowering Forums Religious Harmony and the Establishment of Houses of Worship.

\section{Clossing}

The diversity of ethnic groups, races, cultures and religions, forms of interreligious harmony, there are also several factors that influence religious harmony in life, namely socio-cultural factors and legal factors. The need for higher laws and regulations to regulate individuals in society in a tolerant life and have permanent legal force. The diversity of differences causes conflicts which will later create chaos in social life, the regulation must contain: the form of inter-religious harmony, there are also several factors that affect religious harmony in life. The community has the same rights and obligations in determining social life in accordance with the way of belief. Conflicts that have arisen so far because there are differences which have not been accepted by individuals or community groups so that the Government needs to follow up on a higher regulation to regulate and

\footnotetext{
${ }^{24}$ Rika Marlina, "Pembagian Kekuasaan dalam Penyelenggaraan Di Indonesia", Jurnal Daulat Hukum Vol. 1, No. 1 (2018), p. 173, url: Pembagian Kekuasaan Dalam Penyelenggaraan Pemerintahan Di Indonesia | Marlina | Jurnal Daulat Hukum (unissula.ac.id).
} 
regulate all differences that have occurred so far in order to suppress existing conflicts.

\section{References}

\section{Journals:}

[1] Adhe Ismail Ananda, "Constitution Concept in Implementation of Indonesia State Administration", Jurnal Daulat Hukum, Vo. 4 Issue 2, (2021), p. 123, url: Constitutionalism Concept in Implementation of Indonesian State Administration | Ananda |Jurnal Daulat Hukum (unissula.ac.id)

[2] Chuasanga A., Ong Argo Victoria, "Legal Principles Under Criminal Law in Indonesia and Thailand", Jurnal Daulat Hukum, Vol 2, No 1 (2019) http://jurnal.unissula.ac.id/index.php/RH/article/view/4218

[3] Eko Rubiyanto and Munsharif Abdul Chalim, "Counter Terrorism: Case Study On The Radicals Religious Group”, Jurnal Daulat Hukum, Vol. 1 Issue 4 (2018), p. 872, url: Counter Terrorism : Case Study On The Radicals Religious Group | Rubiyanto |Jurnal Daulat Hukum (unissula.ac.id).

[4] Febriansyah Ramadhan and Ilham Dwi Rafiqi, "Antinomy of community participation rights in the law on the environmental sector", Jurnal Daulat Hukum vol. 4 Issue 3 (2021), p. 172 url: Antinomy of Community Participation Rights in the Law on the Environmental Sector | Ramadhan | Jurnal Daulat Hukum (unissula.ac.id).

[5] Hasyim Asy'ari, "Politik Hukum Kebebasan Beragama di Indonesia", in Jurnal Hukum Pandecta, Vol. 6, No.1, January 2011, Fakultas Hukum Universitas Diponegoro, Semarang, 2011, p. 1-14

[6] Ibnu Rusydi, Siti Zolehah, "Makna Kerukunan Antar Umat Beragama Dalam Konteks Keislaman dan Keindonesiaan”, Journal for Islamis Studies Vol. 1 No. 1 (2018), url: 339662-makna-kerukunan-antar-umat-beragama-dalabd8bd3a9.pdf (neliti.com).

[7] Rika Marlina, "Pembagian Kekuasaan dalam Penyelenggaraan Di Indonesia", Jurnal Daulat Hukum Vol. 1, No. 1 (2018), p. 173, url: Pembagian Kekuasaan Dalam Penyelenggaraan Pemerintahan Di Indonesia| Marlina|Jurnal Daulat Hukum (unissula.ac.id).

[8] Siti Zuliyah, Triwahyuningsih, "The Implementation of Regional Regulations in the procces of filling in the village civil service", Jurnal Daulat Hukum Vol. 4 Issue 4, (2021) p. 278, url: The Implementation of Regional Regulations in the Process of Filling in the Village Civil Service | Zuliyah | Jurnal Daulat Hukum (unissula.ac.id)

\section{Books}

[1] Ahmad, H. A., 2014, Resolusi Konflik Keagamaan di Berbagai Daerah. Jakarta: Kementerian Agama RI Badan Litbang dan Diklat Pusblitang Kehidupan Keagamaan.

[2] Amin, M., 2017, Melawan Terorisme dengan Islam. Jakarta: Tim Penanggulangan Terorisme.

[3] Asy'ari, H., 2011, Politik Hukum Kebebasan Beragama di Indonesia. Jakarta: Bumi Aksara. 
[4] Durkheim, E., 2014, The Elementary Form of the Religion, Terjemah. Yogyakarta: Diva Press.

[5] Ismail, F., 2014, Dinamika Kerukunan Antar Umat Beragama. Bandung: Remaja Rosdakarya.

[6] Keagamaan, T. P., 2014, Menggali Kearifan Memupuk Kerukunan. Jakarta: Puslitbang Kehidupan Keagamaan.

[7] Masduki, I., 2011, Berislam Secara Toleransi. Bandung: Mizan.

[8] MD, M. M., 2014, Politik Hukum di Indonesia. Jakarta: PT Raja Grafindo Persada.

[9] Saebani, B. A., 2008, Metode Penelitian. Bandung: CV Pustaka Setia.

[10] Soekanto, S., 2001, Pengantar Penelitian Hukum. Jakarta: UI Press.

[11] Tholkhah, I., 2013, Survei Nasional Kerukunan Umat Beragama di Indonesia. Jakarta: badan Litbang dan Diklat Puslitbang Kehidupan Beragama.

\section{Internet}

[1] Masykuri Abdillah, 12 January 2015, Merawat Kerukunan Umat Beragama, Sekolah Pascasarjana | MERAWAT KERUKUNAN UMAT BERAGAMA (uinjkt.ac.id), accessed on 14 September 2021

[2] Jaja Sudarno, 21 June 2017, "Tri Kerukunan Umat Beragama”, Tri Kerukunan Umat Beragama (kemenag.go.id), accessed on 15 September 2021 